\title{
Sunset Yellow and Allura Red modulate Bcl2 and COX2 expression levels and confer oxidative stress-mediated renal and hepatic toxicity in male rats
}

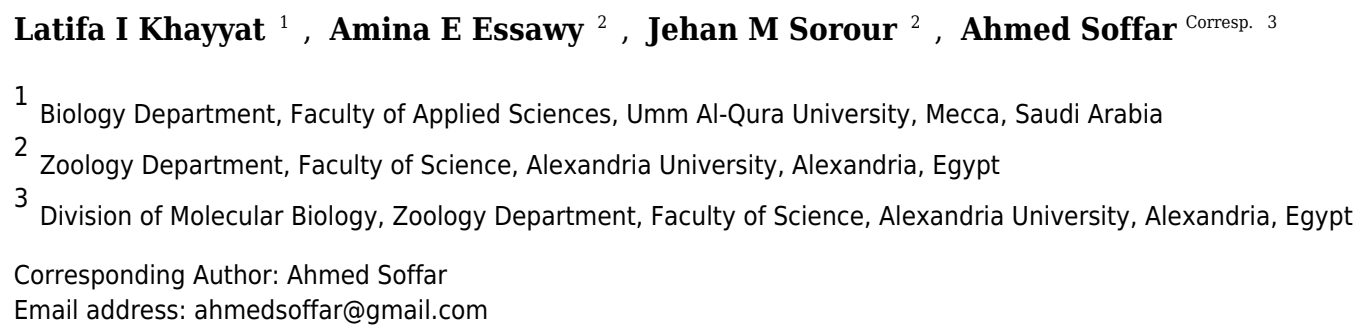

Studies on the adverse health effects caused by azo dyes are insufficient and quite contradictory. This work aims to investigate the possible toxic effect of two types of widely used food additives, Sunset Yellow and Allura Red, by assessing the physiological, histopathological and ultrastructural changes in the liver and kidney. Also, we investigated the genotoxic effect of both dyes on white blood cells. Thirty adult male albino rats were divided into 3 groups of 10 animals each: control (received water), Sunset Yellow-treated ( $2.5 \mathrm{mg} / \mathrm{kg}$ body weight) and Allura Red-treated ( $7 \mathrm{mg} / \mathrm{kg}$ body weight). The doses were orally applied for 4 weeks. Our results indicated an increase in the biochemical markers of hepatic and renal function (Aspartate aminotransferase, alanine aminotransferase, urea, uric acid and creatinine) in animals administered with the azo dyes. We also observed a noticeable increase in MDA and a marked decrease in total antioxidant levels in azo dyetreated animals compared to controls. Conversely, both dyes adversely affected the liver and kidney of albino rats and altered their histological and fine structure, with downregulation of $\mathrm{BCl} 2$ and upregulation of COX2 expression. Our comet assay results showed a significant elevation in the fold change of tail moment in response to application of Sunset Yellow but not Allura Red. Collectively, we show that Sunset Yellow and Allura Red cause histopathological and physiological aberrations in the liver and kidney of male Wistar albino rats. Moreover, Sunset Yellow but not Allura Red induces a potential genotoxic effect. 


\section{Manuscript to be reviewed}

1 Sunset Yellow and Allura Red modulate Bcl2 and COX2 expression levels and

2 confer oxidative stress-mediated renal and hepatic toxicity in male rats

3

4 Latifa I. Khayyat ${ }^{1}$, Amina E. Essawy ${ }^{2}$, Jehan M. Sorour ${ }^{2}$, Ahmed Soffar $^{3 *}$

5

6 'Biology Department, Faculty of Applied Sciences, Umm Al-Qura University, Mecca,

7 Saudi Arabia

8 2Zoology Department, Faculty of Science, Alexandria University, Moharram Bek,

9 Alexandria, Egypt

$10{ }^{3}$ Division of Molecular Biology, Zoology Department, Faculty of Science, Alexandria

11 University, Moharram Bek, Alexandria, Egypt

12

13

14

15

*Corresponding author:

16 E-mail: ahmedsoffar@alexu.edu.eg (Dr. A. Soffar)

17 
18 Abstract

19 Studies on the adverse health effects caused by azo dyes are insufficient and quite contradictory. This work aims to investigate the possible toxic effect of two types of widely used food additives, Sunset Yellow and Allura Red, by assessing the physiological, histopathological and ultrastructural changes in the liver and kidney. Also, we investigated the genotoxic effect of both dyes on white blood cells. Thirty adult male albino rats were divided into 3 groups of 10 animals each: control (received water), Sunset Yellow-treated $(2.5 \mathrm{mg} / \mathrm{kg}$ body weight) and Allura Red-treated (7 $\mathrm{mg} / \mathrm{kg}$ body weight). The doses were orally applied for 4 weeks. Our results indicated an increase in the biochemical markers of hepatic and renal function (Aspartate aminotransferase, alanine aminotransferase, urea, uric acid and creatinine) in animals administered with the azo dyes. We also observed a noticeable increase in MDA and a marked decrease in total antioxidant levels in azo dye-treated animals compared to controls. Conversely, both dyes adversely affected the liver and kidney of albino rats and altered their histological and fine structure, with downregulation of $\mathrm{Bcl} 2$ and upregulation of COX2 expression. Our comet assay results showed a significant elevation in the fold change of tail moment in response to application of Sunset Yellow but not Allura Red. Collectively, we show that Sunset Yellow and Allura Red cause histopathological and physiological aberrations in the liver and kidney of male Wistar albino rats. Moreover, Sunset Yellow but not Allura Red induces a potential genotoxic effect. 


\section{Manuscript to be reviewed}

40

41

42

43

44

45

46

47

48

49

50

51

52

53

54

55

56

57

58

59

60

61

62

63

64

65

66

67

68

69

70

71

72

73

\section{Introduction}

Synthetic food dyes are currently considered one of the most dangerous food additives. Their use in food stuffs raises a series of doubts regarding their cytotoxicity, due to the limited work evaluating the cytotoxicity of these compounds (Feng, Cerniglia \& Chen, 2012). Nonetheless, the possible harmful effect of synthetic food colouring additives is a subject of public health concerns and has a critical attitude toward their use in food preparation.

In general, synthetic azo dyes are considered the most versatile class of dyes, accounting for about 50\% of the dyes produced every year (Puvaneswari, Muthukrishnan \& Gunasekaran, 2006). The toxic adverse effects of the azo dyes are not a result of the native dye but the toxic derivatives, such as aniline, toluene, benzidine and naphthalene, formed during the dye degradation process (Gomes et al., 2013). The impacts of degraded products of azo dyes on human health have caused concern over the last few years. Some azo dyes have been linked to an increased incidence of bladder cancer, splenic sarcomas and hepatocarcinomas in humans and animals (Puvaneswari, Muthukrishnan \& Gunasekaran, 2006).

Sunset Yellow and Allura Red are among the most commonly used azo dyes in the food industry worldwide. These dyes are used in foodstuffs, pharmaceutical products and cosmetics, as yellow and red colouring agents (Hashem et al., 2010). The current literature on the adverse health effects caused by Sunset Yellow and Allura Red is insufficient and quite contradictory. For example, Sasaki et al. (2002) reported that the application of Sunset Yellow did not induce cellular aberrations in stomach cells of mice that orally received the maximum allowed dose. Conversely, other research suggested that administration of Sunset Yellow causes mutagenic or carcinogenic effects in human (Sarhan, Shati \& Elsaid, 2014). Histopathological alterations in the testes and various brain regions of rats have also been demonstrated, as a consequence of dietary exposure to Sunset Yellow (Mathur et al., 2005; Khiralla, Salem \& El-Malky, 2015). Interestingly, Allura Red has been previously classified in one study as a nongenotoxic compound (Combes \& Haveland-Smith, 1982) while in another recent work, it has been evaluated as a genotoxic agent (Jabeen et al., 2013).

Due to these contradicting observations, additional investigations are necessary to assess the potential adverse effects of Sunset Yellow and Allura Red. Hence, in this work, we raised the question of whether applying low doses of Sunset Yellow and Allura Red would adversely affect the liver and kidney structure and function. We also 


\section{Manuscript to be reviewed}

74 evaluated the possible genotoxic potential of both dyes on white blood cells, using the

75

76

77

78

79

80

81

82

83

84

85

86

87

88

89

90

91

92

93

94

95

96

97

98

99

100

101

102

103

104

105

106 single cell electrophoresis assay (comet assay).

\section{Materials and Methods}

Thirty Wistar albino adult male rats of about $150 \mathrm{~g}$ body weight (b.wt) were used in this work. Rats were kept in our animal facility for about 1 week before starting the experiment, for acclimatisation to the laboratory conditions.

Animals were housed in small plastic cages, maintained under constant conditions and were fed on a standard basal diet, as previously described in Khayyat et al. (2017). Our experimental procedures were approved by the Menoufia University IACUC Committee for Care of Laboratory Animals (Approval No.: MNSP155).

Sunset Yellow (CAS 2783-94-0; 90\% purity) and Allura Red (CAS 25956-176; 80\% purity) were purchased from Sigma-Aldrich (Germany).

\section{Experimental design}

The animals were randomly divided into 3 groups (a control group and two treated groups) of 10 rats each, and were treated daily for 30 days, as follows:

Group 1: Animals were orally given distilled water (1 $\mathrm{ml} / \mathrm{kg}$ b.wt.) and served as controls.

Group 2: Animals were orally given Sunset Yellow (2.5 mg/kg b.wt.) dissolved in $1 \mathrm{ml}$ of distilled water (Doguc et al., 2013).

Group 3: Animals were orally given Allura Red (7 mg/kg b.wt.) dissolved in $1 \mathrm{ml}$ of distilled water (Doguc et al., 2013).

At the end of the experiment, the animals from all 3 groups were sacrificed under anaesthesia. Blood samples were collected in sterile centrifuge tubes and allowed to clot. After centrifugation (3500 rpm, $15 \mathrm{~min}$ ), sera of different samples were separated, transferred into empty tubes and biochemically analysed.

For the comet assay, other blood samples were collected, to isolate leucocytes. Regarding the histological and immunohistochemical examinations, pieces of liver and kidney were fixed in Bouin's fluid. For ultrastructure studies, small pieces of the same organs were immersed in $4 \mathrm{~F} 1 \mathrm{G}$ fixative.

\section{Biochemical analysis}


108 (ALT), urea, uric acid, creatinine, nitric oxide (NO), total antioxidant capacity (TAC)

109 and malondialdehyde (MDA) were estimated, as detailed by Khayyat et al. (2017).

110

\section{Histological and ultrastructural studies}

Fixed tissues were dehydrated, cleared and embedded in paraffin wax. Paraffin

113

114

115 sections of $5 \mu \mathrm{m}$ thick were collected onto glass slides, deparaffinised and stained with haematoxylin and eosin (Bancroft \& Gamble, 2002).

For the ultrastructural investigation, tissues were prepared as indicated by Khayyat et al. (2017) before visualisation under a Jeol 100CX electron microscope.

\section{Immunohistochemical study}

Sections from the kidney were loaded on charged slides and incubated overnight at $37{ }^{\circ} \mathrm{C}$, for immunolabelling. Primary antibodies of Bcl2 (Clone 100/D5, Thermo Scientific, USA) and COX2 (Thermo Scientific, USA) were applied for immunolocalisation using UltraVision ONE detection system (Thermo Scientific, USA), according to the manufacturer's protocol.

\section{Genotoxicity study}

For the comet assay, leucocytes were isolated as specified by Khayyat et al. (2017). Briefly, blood samples were centrifuged for $5 \mathrm{~min}$. The buffy coat layer of leucocytes was collected and frozen as aliquots of $250 \mu \mathrm{l}$ in a cold freezing mixture (RPMI 1640, 10\% DMSO). Prepared samples were stored frozen at $-80{ }^{\circ} \mathrm{C}$ until the comet assay was performed. About $20 \pm 5$ comets were scored per sample, and three different samples for each group were analysed. The tail moment was determined by the OpenComet software (Gyori et al., 2014).

\section{Statistical analysis}

The biochemical and comet assay data were expressed as mean \pm SD of 3-5 replicates and were statistically evaluated by the Student's $t$-test. The difference between samples was considered statistically significant at $p<0.05$.

\section{Results}




\section{Manuscript to be reviewed}

\section{Biochemical analysis}

141 The administration of Sunset Yellow or Allura Red was associated with 142 alterations in the levels of several biochemical parameters in the plasma of treated rats, 143 as shown in Figure 1. The plasma liver enzymes, AST and ALT, were significantly 144 elevated $(p<0.05)$ in animals treated with either Sunset Yellow or Allura Red as 145 compared to controls. The plasma concentrations of creatinine and urea were also 146 significantly increased in response to the administration of the individual dyes, and both 147 dyes induced a slight non-significant elevation in the level of uric acid compared to the 148 control value. In addition, we observed a significant depletion $(p<0.05)$ in serum total 149 antioxidants, accompanied by a significant elevation in plasma MDA and NO levels in 150 all azo dye-treated animals as compared to the control.

151

152 153

\section{Histological and ultrastructural results}

Regarding the liver sections of animals treated with the separate dyes, our results show that relative to the control, both dyes adversely affected the liver tissue of treated animals. Among the destructive effects in the liver, were the disorganisation of hepatic strands, as well as necrotic and hydropic degeneration of hepatic cells (Figs. 2a \& 3a). Many hepatocytes were filled with vacuoles of variable size while others appeared with irregular-shaped or pyknotic nuclei (Figs. 2b \& 3b). We also observed marked damage in the central vein region and congestion of blood sinusoids (Figs. 2a \& 3a). Furthermore, we noticed remarkable leucocytes infiltration and an increased number of Kupffer cells in the liver sections of treated animals when compared to the controls.

Our electron micrographs revealed alterations in the regular structure of the hepatocytes of animals treated with Sunset Yellow or Allura Red. The cytoplasmic organelles were clumped and separated by rarified cytoplasm. Degenerated mitochondria and densely packed rough endoplasmic reticulum were also evident (Figs. $2 c \& 3 c)$. Lipid droplets, fibrous tissue proliferation and myelin bodies were recorded (Figs. 2d \& 3d). In addition, some nuclei of hepatocytes exhibited chromatin clumping, and some of these nuclei appeared pyknotic (Figs. 2c \& 3d).

Histological examination of kidney tissue from rats administered with the individual dyes revealed several degenerative structural changes in the renal tubules and glomeruli. Vacuolisation, necrosis and sloughing of tubular epithelium, as well as infiltration of inflammatory cells in-between kidney tubules, were apparent (Figs. 4a \& 


\section{Manuscript to be reviewed}

174 5a). Some glomeruli were obliterated and had thickened Bowman's capsules. Some

175 Malpighian corpuscles appeared with lobulation and dilation of Bowman's space, and

176 vacuolation in the glomeruli and periglomerular haemorrhage were noted (Figs. 4b \& $1775 b)$.

178 Concerning the ultrastructure investigation of renal tubular cells from the 179 kidney of animals treated with Sunset Yellow or Allura Red, most proximal and distal 180 tubular cells revealed destroyed cytoplasm. Pleomorphic cytoplasmic vacuolation and 181 loss of normal parallel basal arrangement of mitochondria in cells of proximal 182 convoluted tubules were noticed (Figs. 4c \& 5c). Most mitochondria were markedly 183 condensed and had lost their cristae. Irregular-shaped dense lysosomes and pyknotic 184 nuclei with condensed chromatin were seen in some of the proximal tubules (Figs. 4c $185 \& 5 \mathrm{c})$. Meanwhile, many cells lining the distal tubules exhibited destroyed apical parts, 186 electron-dense mitochondria, copious hydropic vacuoles and numerous lysosomes. The 187 nuclei appeared irregular, small, atrophic or pyknotic (Figs. $4 d \& 5 d$ ).

188

189

190

191

192

193

194

195

196

197

198

199

200

201

202

203

204

205

\section{Immunohistochemical analysis of $\mathrm{Bcl} 2$ and $\mathrm{COX} 2$ expression levels}

$\mathrm{Bcl} 2$ expression levels were visibly reduced in kidney tissues of both Sunset Yellow- and Allura Red-treated animals in comparison to the controls (Figs. 6a-c).

Regarding COX2 expression, despite finding a discernible basal level in the controls, COX2 levels were remarkably increased in the kidney tissues of Allura Red-treated animals (Figs. 6d \& 6f). The application of Sunset Yellow did not alter the COX2 expression levels relative to the control (Fig. 6e).

\section{Genotoxicity}

We investigated the integrity of the genomic content of leucocytes in response to the respective dyes, by using the comet assay. Our results showed a significant genotoxic effect induced in response to Sunset Yellow administration over the controls, as evidenced by an elevated tail moment of the nuclei of leucocytes of Sunset Yellowtreated animals (Fig. 7). Instead, application of Allura Red did not induce any significant genotoxic effects on the leucocytes of rats.

\section{Discussion}


The present study investigated the effect of the azo dyes, Sunset Yellow and

207 Allura Red, on the renal and hepatic structure and function, antioxidant status, along with the genotoxic effect on white blood cells of rats. The ALT and AST serum levels increased in rats treated with the separate dyes, indicating obstructive damage in the liver tissue. These findings are corroborated by several recent studies that showed a marked increase in the liver transaminases of animals following ingestion of low doses of synthetic colourants (Sarhan, Shati \& Elsaid, 2014; Abd Elhalem et al., 2016; Khayyat et al., 2017). This effect is possibly due to increased cell permeability of hepatocytes. As a result, cytoplasmic enzymes, such as transaminases, leak into the circulation and their activities in the serum increase (Hashem et al., 2010).

Significant elevations in the biochemical parameters of creatinine, urea and uric acid were recorded in the serum of animals treated with Sunset Yellow and Allura Red, respectively, relative to the controls. These biochemical parameters reflect the status of the renal function and can be increased in all forms of kidney injuries (Amin, Abdel Hameid \& Abd Elsttar, 2010). Similar observations were previously reported in rats treated with Sunset Yellow (Tawfek et al., 2015; Abd Elhalem et al., 2016), tartrazine (Khayyat et al., 2017) and Fast Green (Ashour \& Abdelaziz, 2017). The same parameters can be used to classify a food colourant as a harmful agent, depending on its metabolic activation to form free radicals.

Food azo dyes, such as Sunset Yellow and Allura Red, are metabolised by intestinal bacteria, producing free oxygen radicals (Bansal et al., 2005; Shimada et al., 2010). The formed free radicals can induce lipid peroxidation, which causes cell membrane damage, leading to a cascade of pathological events. We investigated the level of lipid peroxidation by measuring the level of MDA, one of the end-products of lipid peroxidation. Interestingly, the levels of MDA significantly increased in rats treated with Sunset Yellow or Allura Red, indicating an increased oxidative stress due to over-production of reactive oxygen species. Our findings concur with Sarhan, Shati and Elsaid (2014) and Khayyat et al. (2017), who reported an elevation of serum MDA after treatment of rats with food chemical colourants. Moreover, Gil (2014) demonstrated that Sunset Yellow induces the oxidative stress response in H295R cells in vitro.

Our results showed an increase in the level of $\mathrm{NO}$, which is considered as a biomarker of oxidative stress. NO is a free radical that might contribute to alterations in energy metabolism. The excessive production of NO may cause oxidative stress, by 
240 forming peroxynitrite with the superoxide anion. Consistent with our data, Peresleni et

241 al. (1996) found that oxidative stress to epithelial cells increases NO production, thereby increasing nitrite formation and decreasing cell viability.

The measurement of antioxidant capacity is an appropriate indication for the total antioxidant defences of various kinds of tissues and organs (Ferrara, Gerber \& LeCouter, 2003). Our study showed a reduced antioxidant capacity in rats treated with the dyes that can be attributed to the accelerated production of free radicals during Sunset Yellow or Allura Red metabolism. Likewise, administration of low doses of tartrazine has been shown to induce depletion of the TAC (Khayyat et al., 2017), possibly because of an increased free radical generation or impaired antioxidant machinery, leading to increased oxidative stress. According to Francés et al. (2013), oxidative stress may result from a general increase in the level of reactive oxygen species, a drop in the normal antioxidant systems or both.

The present investigation identified many histopathological and ultrastructural alterations in the liver and kidney of rats treated with Sunset Yellow and Allura Red, individually, and suggest a possible cytotoxic activity of both dyes. Other researchers (Tsuda et al., 2001; Gomes et al., 2013; Bawazir, 2016; Alsolami, 2017) demonstrated similar cytotoxic effects of Sunset Yellow and Allura Red, and their mutagenic action in the liver, kidney, intestinal and germinal cells of animals.

Histopathological examinations revealed alterations in the liver include congestion, fibrosis, leucocytes infiltration, an increased number of Kupffer cells, as well as necrotic and hydropic degeneration in hepatic cells. These changes in the kidney were somewhat comparable to those seen in the liver. Inflammation, necrosis and vacuolisation of the tubular epithelium occurred, in addition to the destruction of glomeruli, with thickening of Bowman's capsule. The hydropic degeneration of hepatocytes and vacuolisation of tubular cells indicate the occurrence of intracellular oedema, as a result of toxicity or immune aggressions (Kosif et al., 2010; Ramos et al., 2015). Meanwhile, the marked increase in infiltration of leucocytes implies a possible inflammatory response in affected tissues, as noted in earlier works (Soltan \& Shehata, 2012; El-Desoky et al., 2017) following exposure to synthetic colouring agents in foods. Deformation of the glomeruli structure may lead to proteinuria, as an intact glomerulus membrane is essential for normal glomerular filtration rate (Nakamura et al., 2004; Louei Monfared, 2013). 
The electron micrographs revealed many hepatocytes with degenerated

274 mitochondria, densely packed rough endoplasmic reticulum, lipid droplets, numerous glycogen particles and pyknotic nuclei. In the kidney, proximal tubule cells appeared with pleomorphic vacuoles, unusual mitochondrial arrangement, heterogeneous dense

277 bodies and abnormal nuclei. Many distal tubule cells exhibited destruction of their 278 apical parts, electron-dense mitochondria, numerous lysosomes and atrophic or pyknotic nuclei. In agreement with these outcomes, Bansal et al. (2005) and Bawazir (2016) verified that administration of Sunset Yellow and Allura Red caused destructive changes in hepatocytes and alterations and damage in the kidney of treated animals. Other authors established that the use of food colouring agents might cause necrosis and pathological alterations in the liver, kidney, spleen tissues and brain cell layers of experimental animals (Mahmoud, 2006; Sarkar, 2013; Sarkar \& Ghosh, 2017). Damaged liver cells with pyknotic nuclei and disrupted proximal and distal tubules were previously reported in the liver and kidney of rats treated with Metanil Yellow (Sarkar \& Ghosh, 2012).

Interestingly, the application of Sunset Yellow or Allura Red alters the expression level of the apoptosis regulatory protein Bcl2 in kidney tissues. Previous experimental data investigating the effect of Sunset Yellow and Allura Red on the levels of $\mathrm{Bcl} 2$ are not yet available. In addition to its anti-apoptotic function, $\mathrm{Bcl} 2$ promotes cell cycling and increases cell resistance to apoptosis (Huang, 1997; Akl et al., 2014). The observed downregulation in the expression levels of Bcl2 may result in increased probability of cell death (Oltvai, Milliman \& Korsmeyer, 1993). Bcl2 also regulates normal mitochondrial homeostasis, including the pore permeability of the mitochondrial membranes (Vander Heiden \& Thompson, 1999). Hence, the ultrastructural alterations evidenced in the mitochondria may be attributed to the decrease in the Bcl2 levels upon Sunset Yellow or Allura Red treatment. On the contrary, the level of COX2 was elevated upon treatment with Allura Red. It is considered as a pro-inflammatory enzyme, secreted by inflamed tissues (Gilroy et al., 1999), which supports our histopathological observations that indicate inflammatory changes in kidney tissues.

The genotoxic analysis of Sunset Yellow and Allura Red in this work confirmed that Sunset Yellow induced a slight genotoxic effect. Allura Red did not show any remarkable DNA damage in white blood cells, as monitored by the comet assay. Sweeney, Chipman and Forsythe (1994) mentioned that direct-acting oxidative 
307 genotoxicity might be induced by azo dyes, including Sunset Yellow, in vitro. Also,

308 Poul et al. (2009) investigated the genotoxic effect of Sunset Yellow, using the gut 309 micronucleus assay in mice after two administrations of 20,200 or $1000 \mathrm{mg} / \mathrm{kg} \mathrm{b}$.wt at 310 24-h intervals. The authors assessed the genotoxic effects at $24 \mathrm{~h}$ after administration 311 of the food colouring agent, by recording the frequency of micronucleated cells, and 312 cell toxicity by identification of the apoptotic and mitotic cells. They found a slight increase in the incidence of micronucleated cells in response to Sunset Yellow application.

Importantly, the metabolic reduction of Sunset Yellow produces sulphonated aromatic amines. The genotoxicity of some of these sulphonated aromatic amines has been reviewed by Jung, Steinle and Anliker (1992), who concluded that some sulphonated aromatic amines possess extremely low genotoxic potential. Sasaki et al. (2002) conducted an in vivo comet assay, to investigate the genotoxic effect of Sunset Yellow in various tissues of mice after gavage with a single dose of $2 \mathrm{~g} / \mathrm{kg}$ of the food additive. At 3 and $24 \mathrm{~h}$ after administration, Sunset Yellow did not induce genetic aberrations in cells of mice relative to controls. No mutagenic effects were noted in a bone marrow micronucleus assay in vivo after a single oral dose of $2 \mathrm{~g} / \mathrm{kg}$ b.wt Sunset Yellow (Westmoreland \& Gatehouse, 1991).

The in vivo genotoxicity of Allura Red was recently evaluated by Honma (2015) by the induction of DNA damage in the liver and stomach of animals, which concluded that administration of Allura Red was not genotoxic. Another recent study also showed the absence of Allura Red genotoxicity, based on the comet assay, and the in vivo bone marrow micronucleus assay in the liver and colon (Bastaki et al., 2017).

\section{Conclusion}

In conclusion, our data show that Sunset Yellow (2.5 mg/kg b.wt.) and Allura Red (7 mg/kg b.wt.) possess pathological and physiological liver and kidney toxicities in male Wistar albino rats. Sunset Yellow but not Allura Red seems to be slightly genotoxic. 


\section{Manuscript to be reviewed}

\section{References}

338

339

340

341

342

343

344

345

346

347

348

349

350

351

352

353

354

355

356

357

358

359

360

361

362

363

364

365

366

367

368

369

370

371

372

373

374

375

376

377

378

379

380

381

382

Abd Elhalem S., EL-Atrash A., Osman A., Sherif A., Salim E. 2016. Short term toxicity of food additive azo dye, sunset yellow (E110), at low doses, in male Sprague- Dawley rats. Egypt. J. Exp. Biol. (Zool.) 12:13-21.

Akl H., Vervloessem T., Kiviluoto S., Bittremieux M., Parys JB., De Smedt H., Bultynck G. 2014. A dual role for the anti-apoptotic Bcl-2 protein in cancer: Mitochondria versus endoplasmic reticulum. Biochimica et Biophysica Acta (BBA) - Molecular Cell Research 1843:2240-2252. DOI: 10.1016/j.bbamcr.2014.04.017.

Alsolami MA. 2017. Effect of a food additive on certain haematological and biochemical parameters in male albino rat. nternational Journal of Zoology and Research (IJZR) $7: 1-10$.

Amin KA., Abdel Hameid H., Abd Elsttar AH. 2010. Effect of food azo dyes tartrazine and carmoisine on biochemical parameters related to renal, hepatic function and oxidative stress biomarkers in young male rats. Food and Chemical Toxicology: An International Journal Published for the British Industrial Biological Research Association 48:29942999. DOI: 10.1016/j.fct.2010.07.039.

Ashour AA., Abdelaziz I. 2017. Role of fast green on the blood of rats and the therapeutic action of vitamins C or E. Int. J. Integr. Biol. 6:6-11.

Bancroft JD., Gamble M. 2002. Theory and practice of histological techniques. London: Churchill Livingstone.

Bansal AK., Bansal M., Soni G., Bhatnagar D. 2005. Modulation of N-nitrosodiethylamine (NDEA) induced oxidative stress by vitamin $\mathrm{E}$ in rat erythrocytes. Human \& Experimental Toxicology 24:297-302. DOI: 10.1191/0960327105ht533oa.

Bastaki M., Farrell T., Bhusari S., Pant K., Kulkarni R. 2017. Lack of genotoxicity in vivo for food color additive Allura Red AC. Food and Chemical Toxicology: An International Journal Published for the British Industrial Biological Research Association 105:308314. DOI: 10.1016/j.fct.2017.04.037.

Bawazir AE. 2016. Effects of food colour allura red (No. 129) on some neurotransmitter, antioxidant functions and bioelement contents of kidney and brain tissues in male albino rats. Life Science Journal 13:10-17.

Caraway WT. 1955. Determination of uric acid in serum by a carbonate method. American Journal of Clinical Pathology 25:840-845.

Combes RD., Haveland-Smith RB. 1982. A review of the genotoxicity of food, drug and cosmetic colours and other azo, triphenylmethane and xanthene dyes. Mutation Research 98:101-248.

Doguc DK., Ceyhan BM., Ozturk M., Gultekin F. 2013. Effects of maternally exposed colouring food additives on cognitive performance in rats. Toxicology and Industrial Health 29:616-623. DOI: 10.1177/0748233712436638.

El-Desoky GE., Abdel-Ghaffar A., Al-Othman ZA., Habila MA., Al-Sheikh YA., Ghneim HK., Giesy JP., Aboul-Soud M a. M. 2017. Curcumin protects against tartrazine-mediated oxidative stress and hepatotoxicity in male rats. European Review for Medical and Pharmacological Sciences 21:635-645.

Feng J., Cerniglia CE., Chen H. 2012. Toxicological significance of azo dye metabolism by human intestinal microbiota. Frontiers in Bioscience (Elite Edition) 4:568-586.

Ferrara N., Gerber H-P., LeCouter J. 2003. The biology of VEGF and its receptors. Nature Medicine 9:669-676. DOI: 10.1038/nm0603-669. 


\section{Manuscript to be reviewed}

383 Francés DE., Ingaramo PI., Ronco MT., Carnovale CE. 2013. Diabetes, an inflammatory

384

385

386

387

388

389

390

391

392

393

394

395

396

397

398

399

400

401

402

403

404

405

406

407

408

409

410

411

412

413

414

415

416

417

418

419

420

421

422

423

424

425

426

427

428 process: Oxidative Stress and TNF-alpha involved in hepatic complication. Journal of Biomedical Science and Engineering 06:645-653. DOI: 10.4236/jbise.2013.66079.

Gil C. 2014. Toxicological effects of food additives- Azo dyes. Master's Thesis. Sweden: Department of Biomedicine and Veterinary Public Health, Division of Pathology, Pharmacology and Toxicology; Swedish University of Agricultural Sciences.

Gilroy DW., Colville-Nash PR., Willis D., Chivers J., Paul-Clark MJ., Willoughby DA. 1999. Inducible cyclooxygenase may have anti-inflammatory properties. Nature Medicine 5:698-701. DOI: 10.1038/9550.

Gomes KMS., Oliveira MVGA de., Carvalho FR de S., Menezes CC., Peron AP. 2013. Citotoxicity of food dyes sunset yellow (E-110), bordeaux red (E-123), and tatrazine yellow (E-102) on Allium cepa L. root meristematic cells. Food Science and Technology (Campinas) 33:218-223. DOI: 10.1590/S0101-20612013005000012.

Gyori BM., Venkatachalam G., Thiagarajan PS., Hsu D., Clement M-V. 2014. OpenComet: an automated tool for comet assay image analysis. Redox Biology 2:457-465. DOI: 10.1016/j.redox.2013.12.020.

Hashem MM., Atta AH., Arbid MS., Nada SA., Asaad GF. 2010. Immunological studies on Amaranth, Sunset Yellow and Curcumin as food colouring agents in albino rats. Food and Chemical Toxicology 48:1581-1586. DOI: 10.1016/j.fct.2010.03.028.

Honma M. 2015. Evaluation of the in vivo genotoxicity of Allura Red AC (Food Red No. 40). Food and Chemical Toxicology 84:270-275. DOI: 10.1016/j.fct.2015.09.007.

Huang DCS. 1997. The anti-apoptosis function of Bcl-2 can be genetically separated from its inhibitory effect on cell cycle entry. The EMBO Journal 16:4628-4638. DOI: 10.1093/emboj/16.15.4628.

Jabeen HS., ur Rahman S., Mahmood S., Anwer S. 2013. Genotoxicity assessment of amaranth and allura red using Saccharomyces cerevisiae. Bulletin of Environmental Contamination and Toxicology 90:22-26. DOI: 10.1007/s00128-012-0870-x.

Jung R., Steinle D., Anliker R. 1992. A compilation of genotoxicity and carcinogenicity data on aromatic aminosulphonic acids. Food and Chemical Toxicology: An International Journal Published for the British Industrial Biological Research Association 30:635660.

Khayyat L., Essawy A., Sorour J., Soffar A. 2017. Tartrazine induces structural and functional aberrations and genotoxic effects in vivo. PeerJ 5:e3041. DOI: 10.7717/peerj.3041.

Khiralla G., Salem S., El-Malky W. 2015. Effect of Natural and Synthetic Food Coloring Agents on the Balance of Some Hormones in Rats. International Journal of Food Science and Nutrition Engineering 5:88-95.

Kosif R., Yilmaz F., Evrendilek GA., Diramali M. 2010. Histopathological Effects of Aloe barbadensis and Soybean Oil on Rat Liver. International Journal of Morphology 28:1101-1106. DOI: 10.4067/S0717-95022010000400019.

Louei Monfared A. 2013. Histological, ultrastructural and biochemical studies on the kidney of mice treated with Carthamus tinctorius L. extract. Avicenna Journal of Phytomedicine 3:272-278.

Mahmoud H. 2006. Toxic effects of the synthetic food dye brilliant blue on liver, kidney and testes. The egyptian society of toxicology 34:77-84.

Mathur N., Chowhary V., Mehta M., Krishanatrey R. 2005. Effect of sunset yellow on testis in rats. Journal of Ecophysiology and Occupational Health 5:1-3. 


\section{Manuscript to be reviewed}

429 Nakamura S., Terashima M., Kikuchi N., Kimura M., Maehara T., Saito A., Sato M. 2004. A

430

431

432

433

434

435

436

437

438

439

440

441

442

443

444

445

446

447

448

449

450

451

452

453

454

455

456

457

458

459

460

461

462

463

464

465

466

467

468

469

470

471

472

473

474

475

476 new mouse model for renal lesions produced by intravenous injection of diphtheria toxin A-chain expression plasmid. BMC Nephrology 5. DOI: 10.1186/1471-2369-5-4.

Oltvai ZN., Milliman CL., Korsmeyer SJ. 1993. Bcl-2 heterodimerizes in vivo with a conserved homolog, Bax, that accelerates programmed cell death. Cell 74:609-619.

Peresleni T., Noiri E., Bahou WF., Goligorsky MS. 1996. Antisense oligodeoxynucleotides to inducible NO synthase rescue epithelial cells from oxidative stress injury. The American Journal of Physiology 270:F971-977. DOI: 10.1152/ajprenal.1996.270.6.F971.

Poul M., Jarry G., Elhkim MO., Poul J-M. 2009. Lack of genotoxic effect of food dyes amaranth, sunset yellow and tartrazine and their metabolites in the gut micronucleus assay in mice. Food and Chemical Toxicology: An International Journal Published for the British Industrial Biological Research Association 47:443-448. DOI: 10.1016/j.fct.2008.11.034.

Puvaneswari N., Muthukrishnan J., Gunasekaran P. 2006. Toxicity assessment and microbial degradation of azo dyes. Indian Journal of Experimental Biology 44:618-626.

Ramos CAF., Sá R de C da S., Alves MF., Benedito RB., de Sousa DP., Diniz M de FFM., Araújo MST., de Almeida RN. 2015. Histopathological and biochemical assessment of d -limonene-induced liver injury in rats. Toxicology Reports 2:482-488. DOI: 10.1016/j.toxrep.2015.01.001.

Sarhan MAA., Shati AA., Elsaid FG. 2014. Biochemical and molecular studies on the possible influence of the Brassica oleracea and Beta vulgaris extracts to mitigate the effect of food preservatives and food chemical colorants on albino rats. Saudi Journal of Biological Sciences 21:342-354. DOI: 10.1016/j.sjbs.2013.11.004.

Sarkar R. 2013. Histopathological changes in the brain of metanil yellow treated albino rat (Rattus norvegicus). International Journal of Basic and Applied Medical Sciences 3:256-258.

Sarkar R., Ghosh A. 2012. Metanil Yellow-an azo dye induced histopathological and ultrastructural changes in albino rat (Rattus norvegicus). The Bioscan 7:427-432.

Sarkar R., Ghosh A. 2017. Histopathological lesions in spleen of metanil yellow fed albino rat (Rattus norvegicus). International Journal of Scientific Research 6:19-20.

Sasaki YF., Kawaguchi S., Kamaya A., Ohshita M., Kabasawa K., Iwama K., Taniguchi K., Tsuda S. 2002. The comet assay with 8 mouse organs: results with 39 currently used food additives. Mutation Research 519:103-119.

Shimada C., Kano K., Sasaki YF., Sato I., Tsudua S. 2010. Differential colon DNA damage induced by azo food additives between rats and mice. The Journal of Toxicological Sciences 35:547-554.

Soltan SSA., Shehata MMEM. 2012. The Effects of Using Color Foods of Children on Immunity Properties and Liver, Kidney on Rats. Food and Nutrition Sciences 03:897904. DOI: $10.4236 /$ fns.2012.37119.

Sweeney EA., Chipman JK., Forsythe SJ. 1994. Evidence for Direct-Acting Oxidative Genotoxicity by Reduction Products of Azo Dyes. Environmental Health Perspectives 102:119. DOI: $10.2307 / 3432164$.

Tawfek N., Amin H., Abdalla A., Fargali S. 2015. Adverse Effects of Some Food Additives in Adult Male Albino Rats. Current Science International 4:525-537.

Tsuda S., Murakami M., Matsusaka N., Kano K., Taniguchi K., Sasaki YF. 2001. DNA damage induced by red food dyes orally administered to pregnant and male mice. Toxicological Sciences: An Official Journal of the Society of Toxicology 61:92-99.

Peer] reviewing PDF | (2018:02:25295:3:0:NEW 20 Aug 2018) 
Vander Heiden MG., Thompson CB. 1999. Bcl-2 proteins: regulators of apoptosis or of mitochondrial homeostasis? Nature Cell Biology 1:E209-216. DOI: 10.1038/70237.

479 Westmoreland C., Gatehouse DG. 1991. The differential clastogenicity of Solvent Yellow 14 and FD \& C Yellow No. 6 in vivo in the rodent micronucleus test (observations on species and tissue specificity). Carcinogenesis 12:1403-1407.

482

483 


\section{Manuscript to be reviewed}

\section{Explanation of Figures}

485 Fig. (1): Effect of sunset yellow and allura red on serum biochemistry and oxidative

486

487

488

489

490

491

492

493

494

495

496

497

498

499

500

501

502

503

504

505

506

507

508

509

510

511

512

513

514

515

516

517 biomarkers in male rats. (a) Bar graph showing the fold change in the level of measured parameters in response to administration of sunset yellow. (b) Bar graph showing the fold change in the level of measured parameters in response to administration of allura red. Control values are adopted for meta-analysis from Khayyat etal. 2017 and are normalized to 1 (Red line) for all measured parameters. Data are Mean $\pm \mathrm{SD}(\mathrm{n}=3, t$ test, $\left.{ }^{*} p<0.05\right)$.

Fig. (2): Sunset yellow induces histological and ultrastructural alterations in liver tissue of rat. a) LM of liver section from rats treated with sunset yellow showing disorganized hepatic strands, necrosis of most hepatocytes $(\mathrm{H})$, congestion of blood vessel (star). H\&E, Scale bar, $50 \mu \mathrm{m}$. b) LM of liver section from rats treated with sunset yellow showing irregular shaped nuclei $(\mathrm{N})$, thickened blood sinusoid with erythrocytes (star), leucocytic infiltration(I), vacuoles (V) and Kupffer cell (K). H\&E, Scale bar, $20 \mu \mathrm{m} . \mathrm{c})$ EM of liver rats treated with sunset yellow showing cytoplasmic degeneration, electron dense mitochondria (M), clustered rER and pyknotic nuclei (N). Scale bar, $500 \mathrm{~nm} . \mathrm{d}$ ) EM of liver rats treated with sunset yellow showing numerous glycogen particles $(\mathrm{g})$, myelin bodies (my), collagen fibers (star). M, mitochondria; N, nucleus; L, lipid droplets. Scale bar, $500 \mathrm{~nm}$.

Fig. (3): Adverse effect of allura red on the histology and ultrastructure of liver tissue of rat. a) LM of liver section from rats treated with allura red showing hydropic degeneration in hepatocytes $(\mathrm{H})$, damage in central vein (star), leucocytic infiltration (I). H\&E, Scale bar, $50 \mu \mathrm{m}$. b) LM of liver section from rats treated with allura red showing vacuoles in hepatocytes (V), irregular nuclei $(\mathrm{N})$, Kupffer cell (K), leucocytic infiltration (I). H\&E, Scale bar, $20 \mu \mathrm{m}$. c) EM of liver rats treated with allura red showing disrupted hepatocyte, degenerated mitochondria (M), packed rER, lipid droplets (L) and irregular nucleus (N). Scale bar, $500 \mathrm{~nm}$. d) EM of liver rats treated with allura red showing altered mitochondria $(\mathrm{M})$, disintegration $\mathrm{rER}$, lipid droplets (L), pyknotic nucleus (N) and Kupffer cell (K). Scale bar, $500 \mathrm{~nm}$.

Fig. (4): Sunset yellow alters the normal architecture of kidney tissue of rat. a) LM of kidney section from rats treated with sunset yellow showing degenerated renal tubules 
518 (RT) and destructed glomeruli (G). H\&E, Scale bar, $100 \mu \mathrm{m} . \mathrm{b}$ ) LM of kidney section 519 from rats treated with sunset yellow showing vacuolar degenerated renal tubules (RT), 520 vacuoles in glomerulus $(\mathrm{G})$, leukocytes infiltration (I), large vacuole between the 521 tubules (star), haemorrhage (h). H\&E, Scale bar, $50 \mu \mathrm{m}$. c) EM of kidney rat treated 522 with sunset yellow showing proximal tubular cell with altered nucleus $(\mathrm{N})$, condensed 523 mitochondria (M), lysosomes (Ly), vacuoles (star), microvilli (mv). Scale bar, $500 \mathrm{~nm}$.

524 d) EM of kidney rat treated with sunset yellow showing disrupted distal tubular cells 525 with pyknotic nucleus $(\mathrm{N})$, disordered mitochondria (M), vacuolated cytoplasm (star). 526 Scale bar, $500 \mathrm{~nm}$.

Fig. (5): Allura red induces histological and ultrastructural changes in kidney tissue of rat. a) LM of kidney section from rats treated with allura red showing necrosis of renal tubules (RT) and degenerated glomeruli (G). H\&E, Scale bar, $100 \mu \mathrm{m}$. b) LM of kidney section from rats treated with allura red showing vacuolated renal tubules(RT), dilated Bowman's space (star), leukocytes infiltration (I), haemorrhage (h). H\&E, Scale bar, $50 \mu \mathrm{m}$. c) EM of kidney rat treated with allura red showing disrupted proximal tubular cells, irregular nucleus $(\mathrm{N})$, disordered mitochondria (M), lysosomes (Ly), vacuoles (V), microvilli (mv). Scale bar, $500 \mathrm{~nm}$. d) EM of kidney rat treated with allura red showing disrupted distal tubular cells. N, nucleus; M, mitochondria; V, vacuoles. Scale bar, $500 \mathrm{~nm}$.

Fig. (6): Immunohistochemical microscopic images showing the expression of $\mathrm{Bcl} 2$ and $\mathrm{COX} 2$ in the kidney of rat. (a-c) Bcl2 expression levels in control, sunset yellowand allura red-treated animals. Bcl2 expressions are decreased in sunset yellow and allura red as compared to control. (a-f) COX2 expression levels in control, sunset yellow- and allura red-treated animals. Application of sunset yellow did not alter COX2 levels as compared to control. However, application of allura red elevated the expression levels of $\mathrm{COX} 2$ specially in the uriniferous tubules and Malpighian corpuscles. Scale bar, $20 \mu \mathrm{m}$.

Fig. (7): The genetic toxicity of sunset yellow and allura red on white blood cells of rat. Bar graph showing the tail moment in nuclei of leucocytes of control, sunset yellowand allura red-treated animals after Comet Assay. Data are Mean $\pm \operatorname{SD}\left(\mathrm{n}=3, t\right.$-test, ${ }^{*} p$ $<0.05)$. 


\section{Figure 1}

Effect of sunset yellow and allura red on serum biochemistry and oxidative biomarkers in male rats.

(a) Bar graph showing the fold change in the level of measured parameters in response to administration of sunset yellow. (b) Bar graph showing the fold change in the level of measured parameters in response to administration of allura red. Control values are adopted for meta-analysis from Khayyat etal. 2017 and are normalized to 1 (Red line) for all measured parameters.

*Note: Auto Gamma Correction was used for the image. This only affects the reviewing manuscript. See original source image if needed for review. 
(a)

Sunset yellow

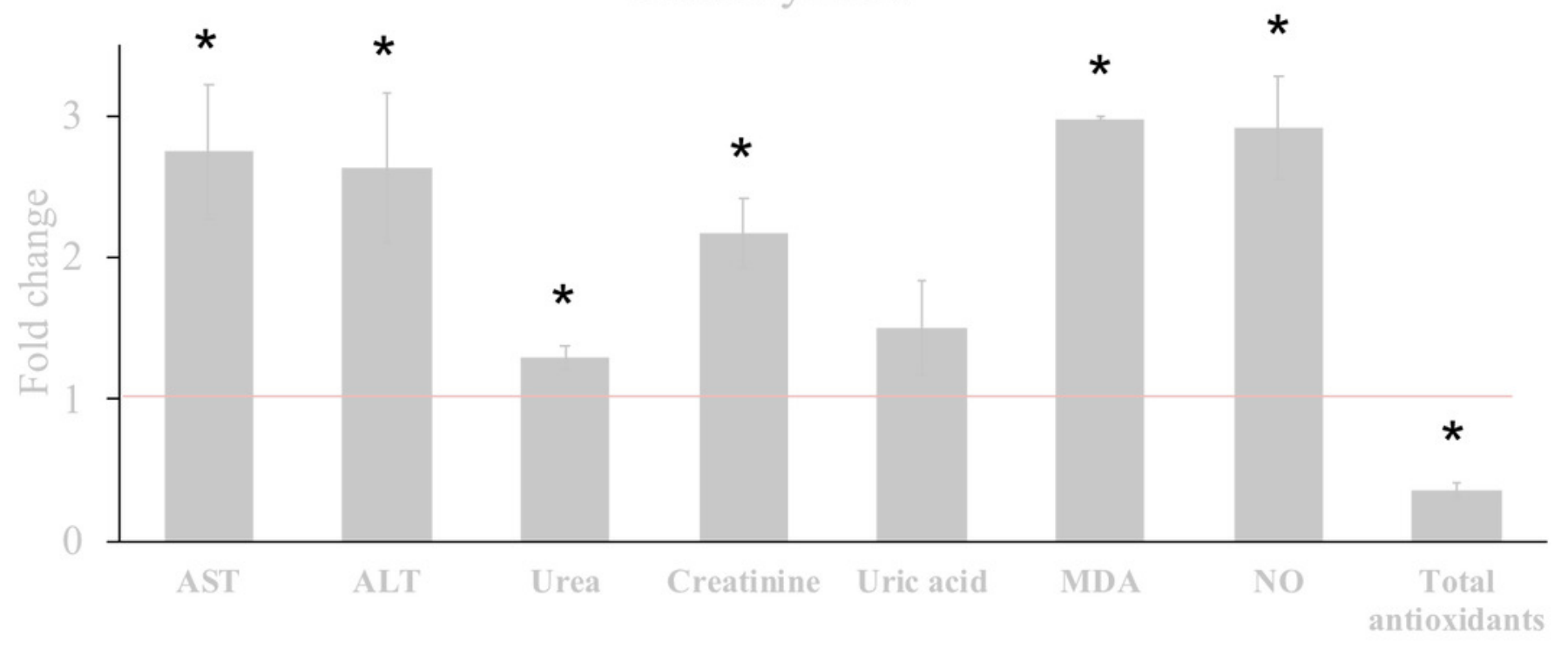

(b)

Allura red

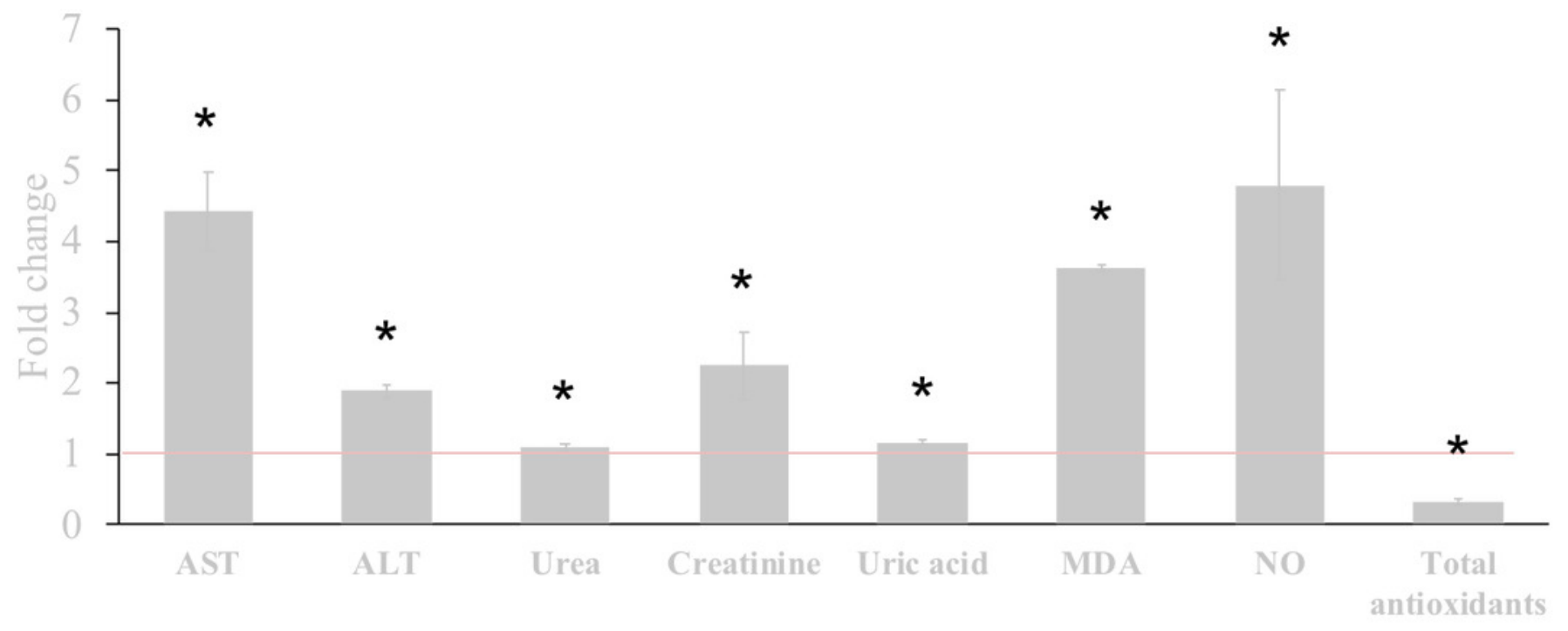




\section{Figure 2}

Sunset yellow induces histological and ultrastructural alterations in liver tissue of rat.

a) LM of liver section from rats treated with sunset yellow showing disorganized hepatic strands, necrosis of most hepatocytes (H), congestion of blood vessel (star). H\&E, Scale bar, $50 \mu \mathrm{m}$. b) LM of liver section from rats treated with sunset yellow showing irregular shaped nuclei (N), thickened blood sinusoid with erythrocytes (star), leucocytic infiltration(I), vacuoles (V) and Kupffer cell (K). H\&E, Scale bar, $20 \mu \mathrm{m}$. c) EM of liver rats treated with sunset yellow showing cytoplasmic degeneration, electron dense mitochondria (M), clustered rER and pyknotic nuclei (N). Scale bar, $500 \mathrm{~nm}$. d) EM of liver rats treated with sunset yellow showing numerous glycogen particles (g), myelin bodies (my), collagen fibers (star). M, mitochondria; N, nucleus; L, lipid droplets. Scale bar, $500 \mathrm{~nm}$. 

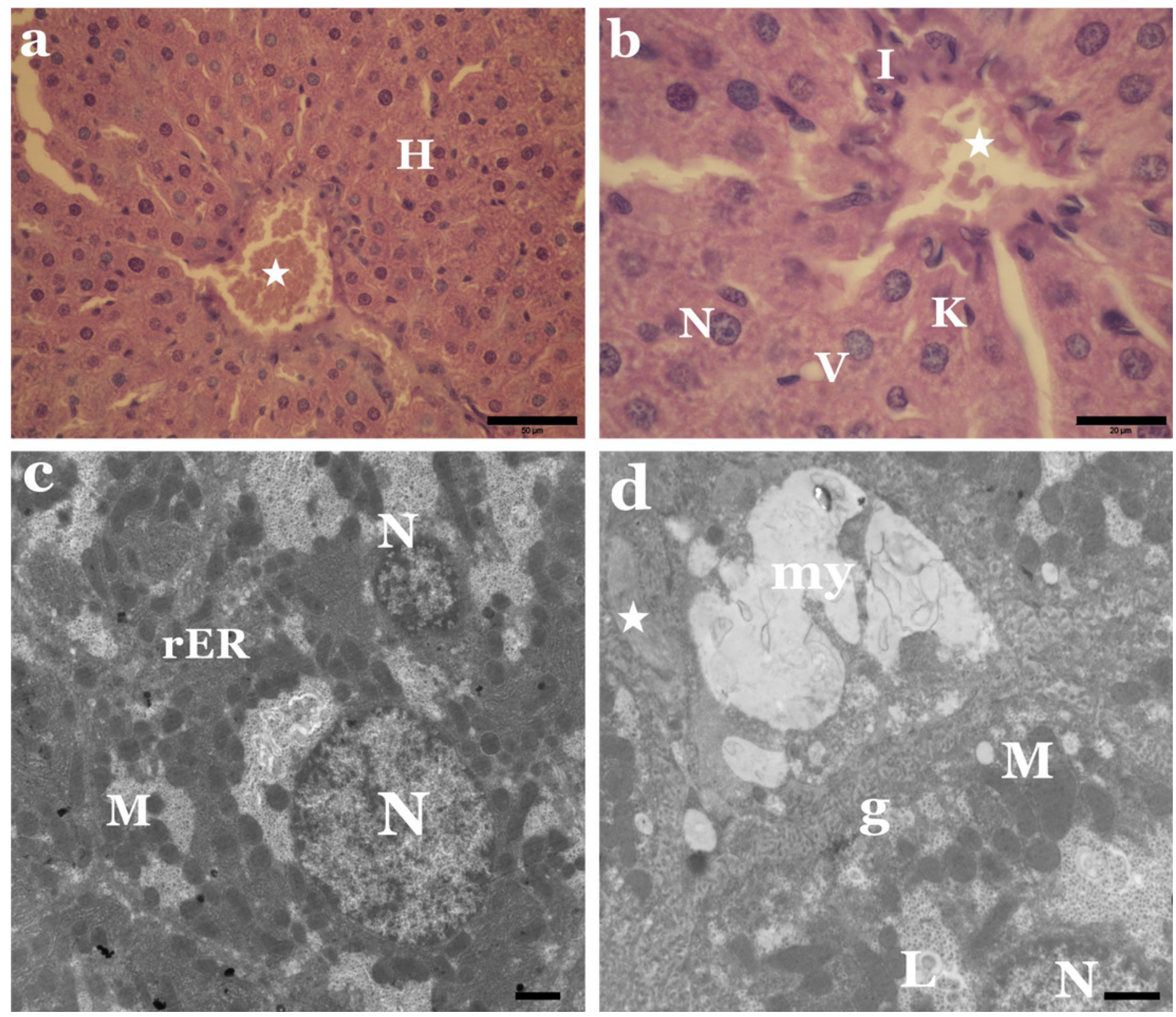


\section{Figure 3}

Adverse effect of allura red on the histology and ultrastructure of liver tissue of rat.

a) LM of liver section from rats treated with allura red showing hydropic degeneration in hepatocytes $(H)$, damage in central vein (star), leucocytic infiltration (I). H\&E, Scale bar, 50 $\mu \mathrm{m}$. b) LM of liver section from rats treated with allura red showing vacuoles in hepatocytes (V), irregular nuclei (N), Kupffer cell (K), leucocytic infiltration (I). H\&E, Scale bar, $20 \mu \mathrm{m} . \mathrm{C}$ ) EM of liver rats treated with allura red showing disrupted hepatocyte, degenerated mitochondria (M), packed rER, lipid droplets (L) and irregular nucleus (N). Scale bar, $500 \mathrm{~nm}$. d) EM of liver rats treated with allura red showing altered mitochondria (M), disintegration rER, lipid droplets (L), pyknotic nucleus (N) and Kupffer cell (K). Scale bar, $500 \mathrm{~nm}$. 

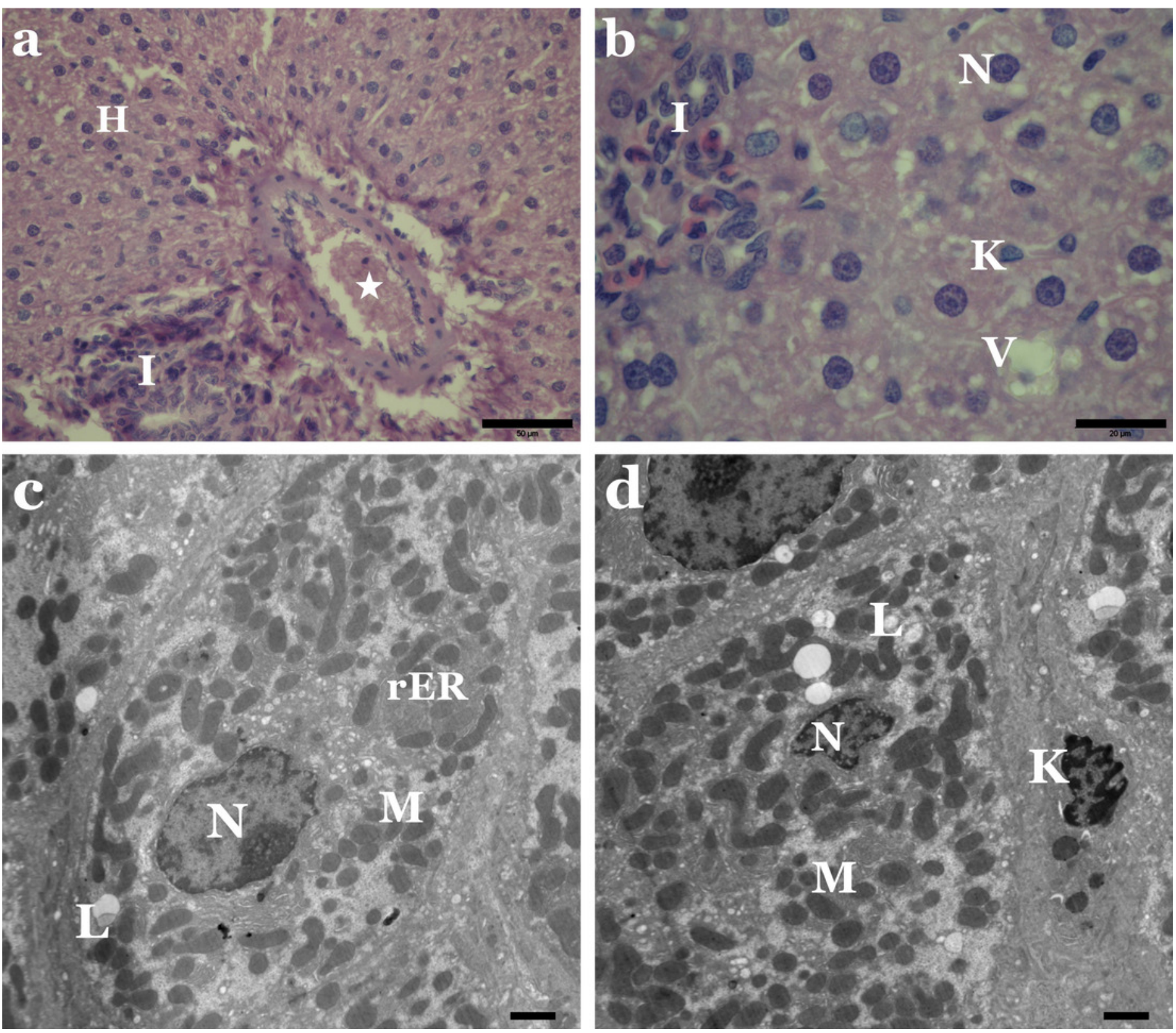


\section{Figure 4}

Sunset yellow alters the normal architecture of kidney tissue of rat.

a) LM of kidney section from rats treated with sunset yellow showing degenerated renal tubules (RT) and destructed glomeruli (G). H\&E, Scale bar, $100 \mu \mathrm{m}$. b) LM of kidney section from rats treated with sunset yellow showing vacuolar degenerated renal tubules (RT), vacuoles in glomerulus $(\mathrm{G})$, leukocytes infiltration (I), large vacuole between the tubules (star), haemorrhage (h). H\&E, Scale bar, $50 \mu \mathrm{m}$. c) EM of kidney rat treated with sunset yellow showing proximal tubular cell with altered nucleus $(\mathrm{N})$, condensed mitochondria (M), lysosomes (Ly), vacuoles (star), microvilli (mv). Scale bar, $500 \mathrm{~nm}$. d) EM of kidney rat treated with sunset yellow showing disrupted distal tubular cells with pyknotic nucleus (N), disordered mitochondria (M), vacuolated cytoplasm (star). Scale bar, $500 \mathrm{~nm}$. 

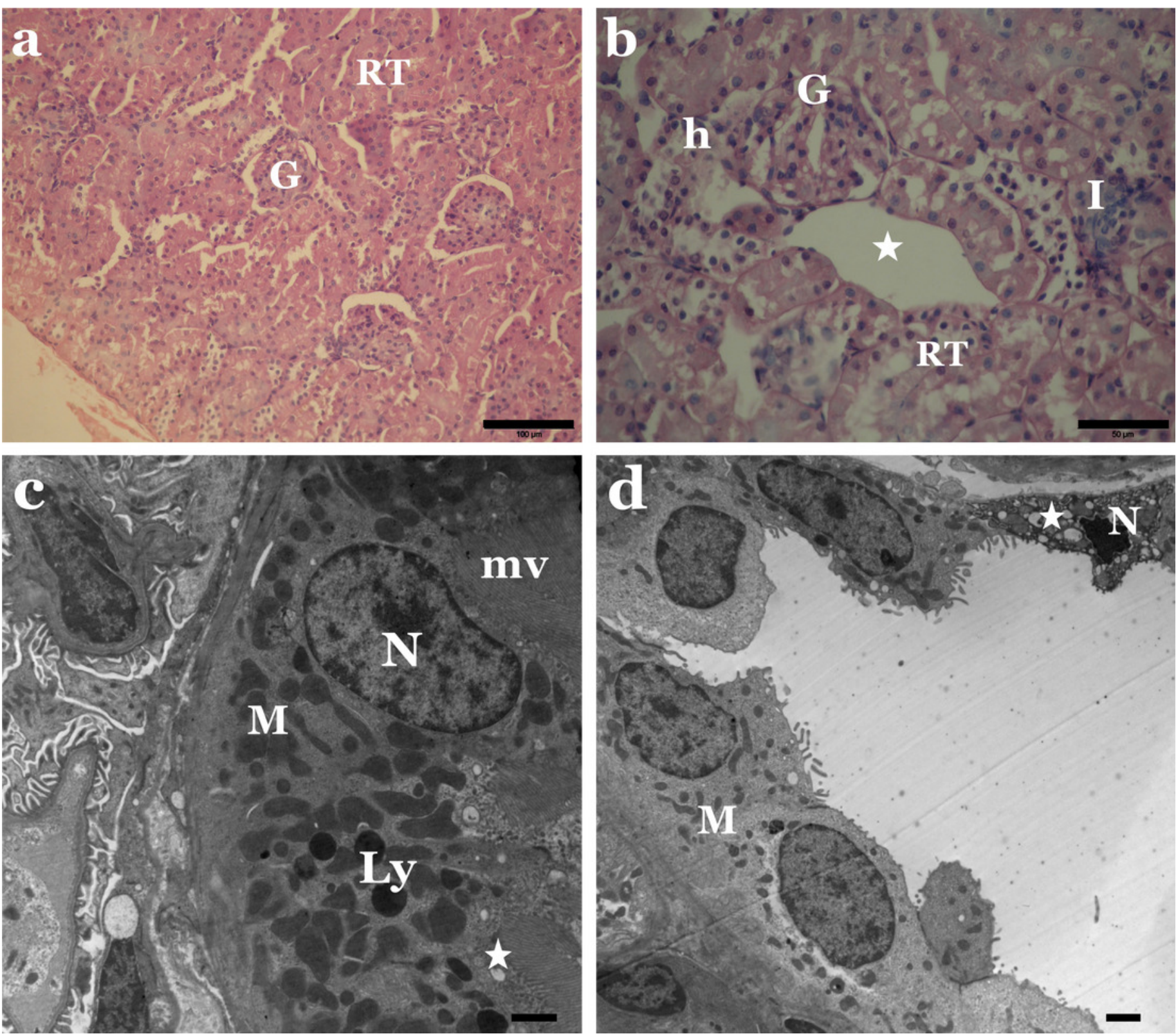


\section{Figure 5}

Allura red induces histological and ultrastructural changes in kidney tissue of rat.

a) LM of kidney section from rats treated with allura red showing necrosis of renal tubules (RT) and degenerated glomeruli (G). H\&E, Scale bar, $100 \mu \mathrm{m}$. b) LM of kidney section from rats treated with allura red showing vacuolated renal tubules(RT), dilated Bowman's space (star), leukocytes infiltration (I), haemorrhage (h). H\&E, Scale bar, $50 \mu \mathrm{m}$. c) EM of kidney rat treated with allura red showing disrupted proximal tubular cells, irregular nucleus (N), disordered mitochondria (M), lysosomes (Ly), vacuoles (V), microvilli (mv). Scale bar, $500 \mathrm{~nm}$. d) EM of kidney rat treated with allura red showing disrupted distal tubular cells. N, nucleus; M, mitochondria; V, vacuoles. Scale bar, $500 \mathrm{~nm}$. 

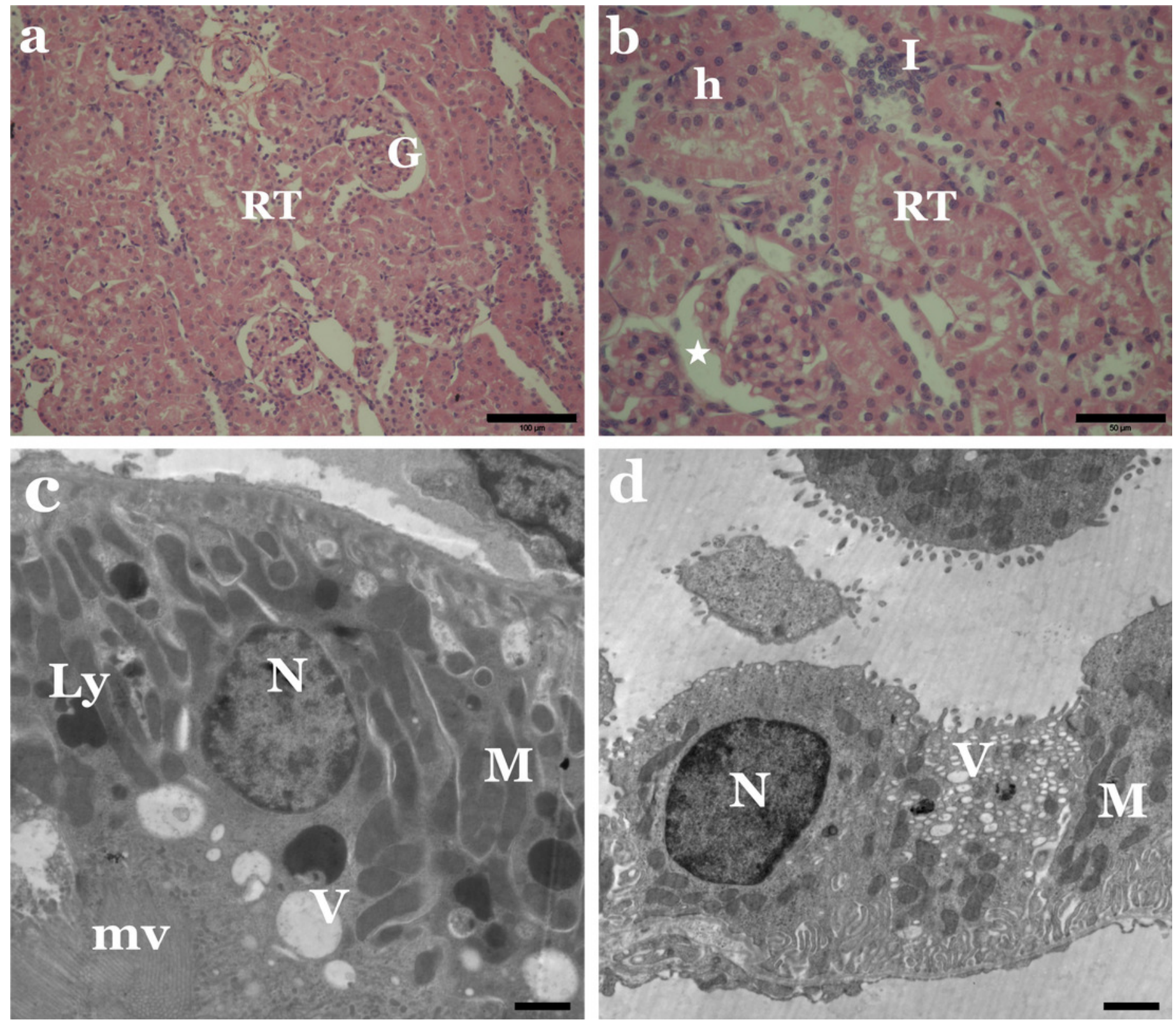


\section{Figure 6}

Immunohistochemical microscopic images showing the expression of $\mathrm{Bcl} 2$ and $\mathrm{COX} 2$ in the kidney of rat.

(a-c) Bcl2 expression levels in control, sunset yellow-, and allura red-treated animals. BCl2 expressions are decreased in sunset yellow and allura red as compared to control. (a-f) COX2 expression levels in control, sunset yellow-, and allura red-treated animals. Application of sunset yellow did not alter COX2 levels as compared to control. However, application of allura red elevated the expression levels of COX2 specially in the uriniferous tubules and Malpighian corpuscles. Scale bar, $20 \mu \mathrm{m}$. 


\section{$\mathrm{Bcl} 2$}
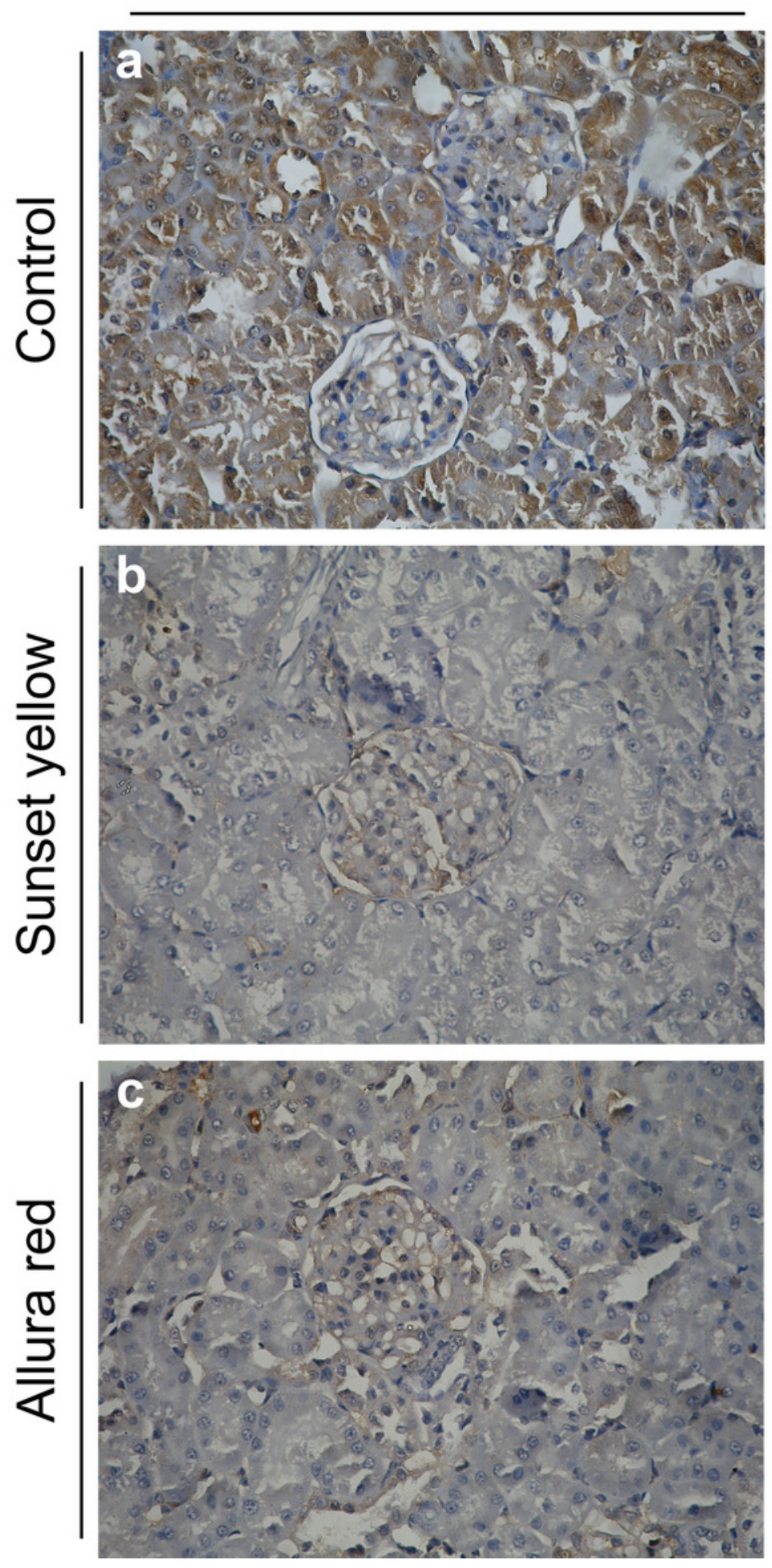

COX2
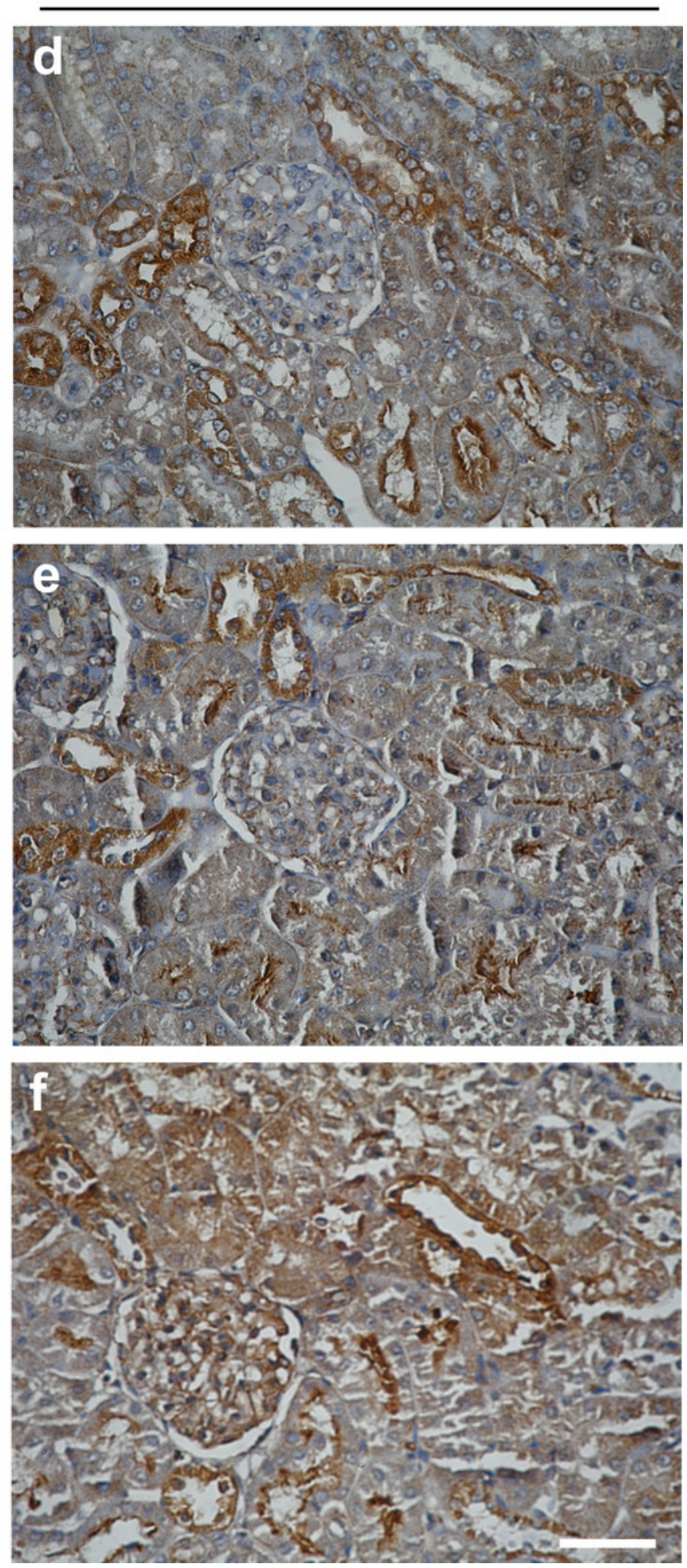


\section{Figure 7}

The genetic toxicity of sunset yellow and allura red on white blood cells of rat.

Bar graph showing the tail moment in nuclei of leucocytes of control, sunset yellow-, and allura red-treated animals after Comet Assay. Data are Mean $\pm \mathrm{SD}\left(\mathrm{n}=3\right.$, t-test, $\left.{ }^{*} \mathrm{p}<0.05\right)$.

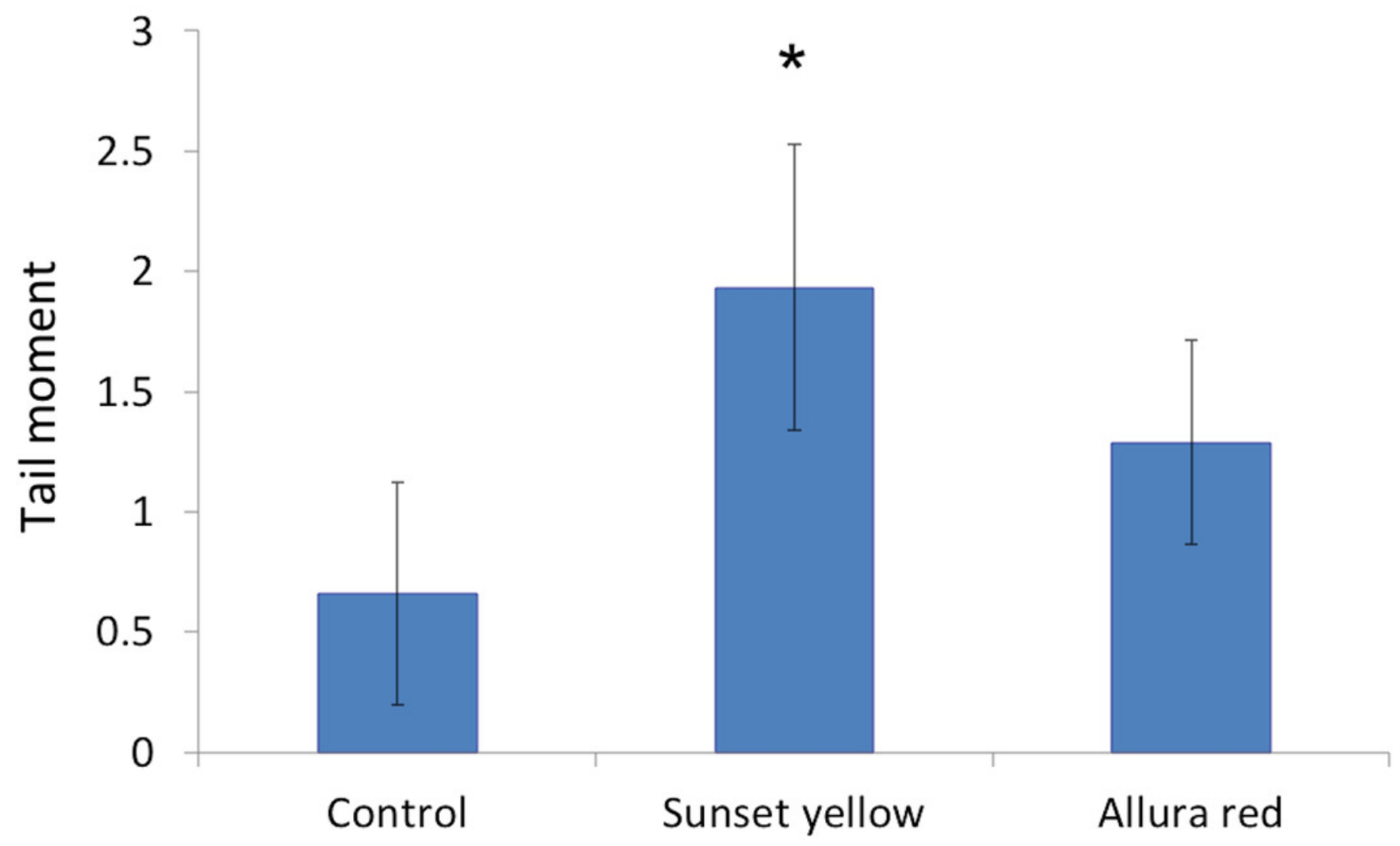

